\title{
Mineralogy of the diamond and its indicator minerals from Archangelsk diamondiferous province
}

\author{
V. K. Garanin and K.V. Garanin \\ M.V. Lomonosov Moscow State University, Moscow, Russia
}

Archangelsk diamondiferous kimberlitic province is on the territory of the European part of Russia. All of discoveries: industrial, low- and non-diamondiferous alkaline-ultrabasic magmatites mainly are located in Zimnyi Bereg area of the province. There are more 60 objects of the kimberlitic and related magmatism, include two industrial diamond deposits - M.V. Lomonosov and V. Grib. There are two contrast types of the kimberlites and related rocks among these magmatites: low- and non-diamondiferous kimberlites, picrites and olivine melilitites. They differ in mineral composition, groundmass specialization, association of the mantle, metamorphic xenoliths and quantity, size, morphology features and physical properties of diamonds (Bogatikov et al., 1999).

Mineralogical identification was done for 42 alkalineultrabasic magmatites from different fields. It allows identifying the typomorphic diamond features and its indicator minerals (DIM) from different pipes, clusters, fields, area as a whole and approaches to Zimnyi Bereg zoning by the mineralogical positions (Garanin, 2006). All available data about content and composition of the most important DIM (garnets, clynopyroxenes, $\mathrm{Cr}$ spinels and ilmenites) are generalized and systematized by the application of the previously designed chemicalgenetic classifications (Garanin et al.). DIM paragenesis were identified include diamondiferous ones. This work was done on the unified methodological basis and statistically presentable material.

Integrated GIS for 42 bodies was created as result of our researches. Mineralogical positioning (zoning) of this territory was also done.

Essential difference was found on comparison diamonds morphology from V. Grib deposit with high diamonds grade (1-1.5 cts/t) and pipes of M.V. Lomonosov deposit with lower diamond grade (0.5-1.0 $\mathrm{cts} / \mathrm{t}$ ). Diamonds granulometry is compatible for both deposits, but diamonds from V. Grib pipe have got better quality than diamonds from M.V. Lomonosov deposit. There is a high quantity of octahedrons (28\%), rhombic dodecahedrons (38\%), transitional forms $(22 \%)$ and lower quantity of cubes $(6 \%)$ and pseudohemimorphic $(6 \%)$ crystals in V. Grib pipe. Tetrahexahedrons content in two times lower than in M.V. Lomonosov deposit. Diamonds from M.V.
Lomonosov deposit usually presented by sub-fissured grayish (42\%) dodecahedrons $(\sim 70 \%)$ with different deformation traces. Octahedrons content $(\sim 10 \%)$ is appreciably lower than in V. Grib pipe. Therefore the conditions of the final diamonds genesis differ sharply for these deposits. Even greater solution with poor diamond grade is character for all magmatites from Verkhotinskoe and Kepinskoe fields (Bogatikov et al., 1999).

Interesting data was received after study of the ilmenite and ilmenite-hyperbasites. Spectrum of the ilmenite mantle rocks in Zimnyi Bereg is limited and presented by Mg-types of the ilmenite ultra-basic paragenesis. The picroilmenite from $\mathrm{V}$. Grib pipe is characterized by anomalous high $\mathrm{Cr}$-content (under 8.6 wt.\% $\mathrm{Cr}_{2} \mathrm{O}_{3}$ ). It is not peculiar for picroilmenites from other Zimnyi Bereg magmatites $\left(<3.5\right.$ wt. $\left.\% \mathrm{Cr}_{2} \mathrm{O}_{3}\right)$. Occurrences of the picroilmenites with high $\mathrm{Cr}$-content ( $>3.5$ wt.\% $\left.\mathrm{Cr}_{2} \mathrm{O}_{3}\right)$ is reliable data for discoveries kimberlites with high diamond grade.

Realized researches and generalization all data are evidences the perspectives of the new diamond deposits discoveries in Archangelsk province and give a possibility to plan the prospecting for new diamond deposits in European part of Russia.

\section{References}

Bogatikov O.A., Garanin V.K., Kononova V.A. et al. Arkhangelsk diamondiferous province (geology, petrography, geochemistry and mineralogy). Moscow, ed. MSU, 1999, $522 \mathrm{p}$.

Garanin V.K. Mineralogy of the kimberlites and related rocks from Russian diamond provinces relative to their genesis and searching. Moscow, ed. Geological Faculty MSU, 2006, 48 p.

Garanin V.K., Kudryavtseva G.P., Marfunin A.S., Mikhailichenko O.A. Inclusions in diamonds and diamond-bearing rocks. Moscow, ed. MSU, 1991, $240 \mathrm{p}$. 
